\title{
PEMBELAJARAN KOOPERATIF TIPE STRUCTURE NUMBERED HEADS PADA MATA PELAJARAN GEOGRAFI
}

\author{
Miftah Hidayat \\ Universitas Pendidikan Indonesia (UPI) Bandung \\ E-mail : hidayatmiftah153@gmail.com
}

Naskah diterima : 13 April 2017, direvisi : 15 Mei 2017, disetujui : 27 Juni 2017

\begin{abstract}
The purpose of this research is to: (1) increase the learning motivation of learners by using Structure Numbered Heads learning method, and (2) to describe the improvement of learning motivation of learners through Structure Numbered Heads learning method. The method used is Classroom Action Research which refers to the model developed by Kemmis and Taggart, this study was conducted in two cycles. One cycle is done as much as two actions. Thus the entire Classroom Action Research was conducted in 4 actions. Data collection techniques are done through observation and documentation. The result of the research shows that learning done with cooperative learning model type Structure Numbered Heads can improve learners motivation. The first action shows the "low" category, the second action shows the "enough" category and the "good" category, while the fourth action shows the "good" category. Increases that occur can not be separated from the use of Structure Numbered Heads method combined with some learning techniques.
\end{abstract}

Keywords: learning motivation, cooperative learning model, structure numbered heads methods.

\begin{abstract}
Abstrak
Tujuan dari penelitian ini adalah untuk: (1) meningkatkan motivasi belajar peserta didik dengan menggunakan metode pembelajaran Structure Numbered Heads, dan (2) mendeskripsikan peningkatan motivasi belajar peserta didik melalui metode pembelajaran Structure Numbered Heads. Metode yang digunakan adalah Penelitian Tindakan Kelas (PTK) yang mengacu pada model yang dikembangkan oleh Kemmis dan Taggart, penelitian ini dilakukan dalam dua siklus. Satu siklus dilakukan sebanyak dua tindakan. Dengan demikian keseluruhan Penelitian Tindakan Kelas ini dilakukan sebanyak 4 tindakan. Teknik pengumpulan data dilakukan melalui observasi dan dokumentasi. Hasil penelitian menunjukkan bahwa pembelajaran yang dilakukan dengan model pembelajaran kooperatif tipe Structure Numbered Heads dapat meningkatkan motivasi belajar peserta didik. Tindakan pertama menunjukkan kategori "rendah", tindakan kedua menunjukkan kategori "cukup" dan tindakan kategori "baik," sementara tindakan keempat menunjukkan "kategori "baik". Peningkatan yang terjadi tidak lepas dari penggunaan metode Structure Numbered Heads yang dipadukan dengan beberapa teknik pembelajaran.
\end{abstract}

Kata kunci: motivasi belajar, model pembelajaran kooperatif, structure numbered heads methods.

Pengutipan: Hidayat, Miftah. (2017). Pembelajaran Kooperatif Tipe Structure Numbered Heads pada Mata Pelajaran Geografi. SOSIO DIDAKTIKA: Social Science Education Journal, 4(1), 2017, 36-44. doi:10.15408/sd.v4i1.5916.

Permalink/DOI: http://dx.doi.org/10.15408/sd.v4i1.5916 


\section{A. Pendahuluan}

Kajian dalam penelitian ini merujuk pada motivasi belajar peserta didik. Motivasi menjadi hal yang penting dalam kegiatan pembelajaran, karena jika motivasi tinggi maka kegiatan belajar bisa berjalan lancar dan materi yang disampaikan akan mudah diserap oleh para peserta didik. Menurut Hamalik bahwa "Motivasi menunjuk kepada semua gejala yang terkandung dalam stimulasi tindakan ke arah tujuan tertentu di mana sebelumnya tidak ada gerakan menuju ke arah tujuan tersebut". ${ }^{.}$Sangatlah penting seorang pendidik untuk bisa membangkitkan motivasi belajar para peserta didiknya. Merujuk pada hal ini seorang pendidik harus bisa membawa peserta didiknya agar apapun tugas yang diberikan tidak dijadikan sebagai beban bahkan menjadi sebuah hal yang menarik dan termotivasi untuk diselesaikan oleh para peserta didik.

Pada pendapat Maslow, motivasi belajar menjadi hal penting sebagaimana dikemukakan Dimyati dan Mudjiono sebagai berikut. Pertama, menyadarkan kedudukan awal belajar, proses, dan hasil akhir. Contohnya setelah seorang peserta didik membaca suatu bab buku bacaan, dibandingkan dengan temannya sekelas yang juga membaca bab tersebut, ia kurang berhasil menangkap isi, maka ia terdorong membaca lagi. Kedua, menginformasikan tentang kekuatan usaha belajar, yang dibandingkan dengan teman sebaya. Sebagai ilustrasi, jika terbukti usaha belajar seorang peserta didik belum memadai, maka ia berusaha setekun temannya yang belajar dan berhasil. Ketiga, mengarahkan kegiatan belajar. Sebagai ilustrasi, setelah ia ketahui bahwa dirinya belum belajar secara serius, terbukti banyak bersenda gurau misalnya, maka ia akan mengubah perilaku belajarnya. Keempat, membesarkan semangat belajar. Sebagai ilustrasi, jika ia telah menghabiskan dana belajar dan masih ada adik yang dibiayai orang tua, maka ia berusaha agar cepat lulus. Kelima, menyadarkan tentang adanya perjalanan belajar dan kemudian bekerja (di sela-selanya adalah istirahat atau bermain) yang berkesinambungan; individu dilatih untuk menggunakan kekuatannya sedemikian rupa sehingga dapat berhasil. ${ }^{2}$

McDonald dalam Hamalik "Motivation is a energy change within the person characterized by affective arousal

1 Oemar Hamalik, Psikologi Belajar dan Mengajar, (Bandung: Sinar Baru Algensindo, 2007), h.173

2 Dimyati dan Mudjiono, Belajar dan Pembelajaran, (Jakarta: Rineka Cipta, 2009), h.85 and anticipatory goal reactions". ${ }^{3}$ Motivasi adalah suatu perubahan energi di dalam pribadi seseorang yang ditandai dengan timbulnya afektif dan reaksi untuk mencapai tujuan Memang cukup sulit untuk melihat pribadi tiap orang di kelas dari peserta didik karena dari jumlah biasanya lebih dari dua puluh lima orang, seperti kelas XI IIS B di SMAN 5 Bandung yang akan menjadi lokasi yang diteliti oleh peneliti yang peserta didiknya berjumlah 28 orang. Ditambah informasi yang peneliti dapat dari pendidik pun bahwa di kelas XI IIS B tersebut motivasi belajar mereka masih sangat kurang. Peserta didik kurang memperhatikan materi yang diberikan. Beberapa ada yang bermain hp, mendengarkan musik dengan earphone, dan mengobrol. Slide yang ditayangkan terkadang tidak dicatat dan bahkan sesudah pembelajaran jarang sekali yang bertanya untuk lebih memperjelas halhal yang belum peserta didik pahami.

Penggunaan metode yang tepat dalam proses belajar mengajar dapat meningkatkan motivasi belajar peserta didik. Dari berbagai macam model dan metode pembelajaran terdapat sebuah metode pembelajaran kooperatif tipe Structured Numbered Heads yang merupakan modifikasi dari tipe numbered heads together. Metode ini dianggap bisa membangkitkan motivasi belajar peserta didik karena terdapat kerjasama antar peserta didik di dalamnya. Seperti yang diungkapkan oleh Miftahul Huda, aktivitas-aktivitas kooperatif jika diterapkan dengan tepat dengan menciptakan suatu kondisi yang di dalamnya setiap anggota berkeyakinan bahwa mereka bisa sukses mencapai tujuan kelompoknya hanya jika teman-teman satu kelompoknya yang lain juga sukses mencapai tujuan tertentu. Dengan asumsi semacam ini, setiap anggota kelompok tentu akan termotivasi untuk membantu anggotaanggota yang lain demi mencapai tujuan mereka bersama-sama. Bahkan yang lebih penting, mereka mendorong teman-temannya untuk memberikan usaha maksimal untuk mencapai tujuan tersebut. ${ }^{4}$

Selain itu juga, model pembelajaran ini jika diterapkan pada pembelajaran geografi khususnya materi biosfer yang membahas tentang lapisan kehidupan di permukaan bumi, akan sangat cocok pada ranah diskusi hasil buah pikir tiap individu peserta didik untuk didiskusikan dengan rekanrekan kelompoknya. Selain itu, pemberian nomor

3 Oemar Hamalik, Psikologi Belajar... h.173

4 Miftahul Huda,. Cooperative Learning, (Yogyakarta: Pustaka Pelajar, 2013), h.34 
dengan tugas yang berbeda pada tiap peserta didik akan memberikan motivasi lebih untuk mengerjakan apa yang memang harus dikerjakannya.

Tujuan dari penelitian ini adalah meningkatkan motivasi belajar peserta didik melalui model pembelajaran kooperatif tipe Structure Numbered Heads dan mendeskripsikan peningkatan motivasi belajar peserta didik melalui metode pembelajaran Structure Numbered Heads.

\section{B. Metode Penelitian}

Penelitian ini dilakukan di SMAN 5 Bandung kelas XII IIS B semester 2 (ganjil) tahun ajaran 2014/2015 yang berlokasi di Jalan Belitung No. 8. Subjek dalam penelitian ini adalah peserta didik kelas XI IIS B dengan jumlah 28 orang yang terdiri dari 13 peserta didik laki-laki dan 15 peserta didik perempuan. Peneliti bertindak sebagai observer dan guru mata pelajaran bertindak sebagai objek penelitian yang melakukan treatment terhadap peserta didik yang menjadi objek penelitian lainnya. Metode yang digunakan adalah Penelitian Tindakan Kelas (PTK) yang mengacu pada model yang dikembangkan oleh Kemmis dan Taggart. Model spiral Kemmis dan Taggart ini meliputi kegiatan plan (perencanaan), act (tindakan), observe (observasi) dan reflect (refleksi).

Kegiatan ini dilakukan dengan sistem kemitraan kerjasama dengan pihak-pihak yang terkait demi tercapainya tujuan kegiatan penelitian tindakan kelas. Kerjasama dilakukan dengan sekolah tempat mengajar, peserta didik, serta guru mata pelajaran di lokasi penelitian. Diskusi mendalam dilakukan dengan guru yang akan mengajar pada saat penelitian sehingga saat penelitian dilakukan bisa berjalan lancar. Model yang digunakan yaitu model spiral dari Kemmis dan Taggart seperti digambarkan berikut ini.

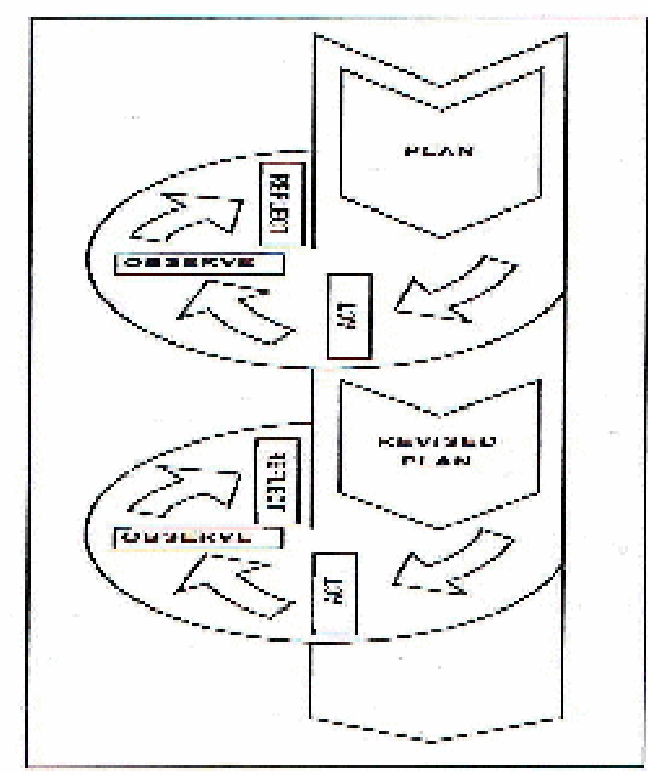

Gambar 1. Model Spiral Kemmis dan Taggart

Aspek yang dikaji pada penelitian ini adalah metode pembelajaran Structure Numbered Heads dan motivasi belajar peserta didik yang terdiri dari dorongan rasa ingin tahu, dorongan pemenuhan kepuasan, dorongan percaya diri dan dorongan untuk mencapai hasil. Instrumen untuk pengumpulan data dilakukan melalui lembar observasi kegiatan pembelajaran dengan menggunakan model Structure Numbered Heads, lembar skala sikap peserta didik (angket), serta catatan lapangan untuk merekam kejadian atau fenomena yang terjadi pada saat penelitian untuk melengkapi hasil dari penelitian yang tidak terekam dalam instrumen yang telah dibuat sebelumnya. Instrumen yang dibuat disesuaikan dengan indikator pencapaian motivasi belajar peserta didik.

Teknik analisis data yang digunakan pada penelitian kali ini yaitu analisis data kualitatif. Teknik analisis data dimulai dengan pengumpulan data observasi kegiatan pembelajaran di kelas, hasil angket dan catatan lapangan. Kemudian dilakukan reduksi data dengan menyeleksi, menfokuskan dan menyederhanakan semua data mentah dan kasar yang telah diperoleh dari lembar motivasi peserta didik dan angket skala motivasi peserta didik. Langkah selanjutnya dilakukan presentase pada skala sikap dan gambaran keseluruhan penelitian dari observasi kegiatan lapangan yang terekam dalam lembar observasi motivasi peserta didik. 


\section{Hasil dan Pembahasan}

\section{Penerapan Pembelajaran Model Pembelajaran Kooperatif tipe Structure Numbered Heads}

Pembelajaran kooperatif tipe Stucture Numbered Heads ini diterapkan di kelas XI IIS B SMAN 5 Bandung. Pembelajaran Structure Numbered Heads ini dimaksudkan untuk meningkatkan motivasi belajar peserta didik di kelas tersebut. Penelitian ini dilakukan sebanyak 2 siklus, dengan 1 siklus terdiri dari 2 tindakan, maka secara keseluruhan penelitian ini dilakukan sebanyak 4 tindakan. Tindakan pertama dilakukan pada hari Kamis tanggal 21 Agustus 2014, tindakan kedua dilaksanakan pada hari Senin tanggal 25 Agustus 2014, tindakan ketiga dilaksanakan pada tanggal 28 Agustus 2014, dan tindakan keempat dilakukan pada tanggal 1 September 2014. Rangkaian tindakan dilakukan melalui proses perencanaan, pelaksanaan tindakan, observasi dan refleksi.

Materi dari tiap tindakan berbeda-beda disesuaikan dengan materi di sekolah yang bersangkutan. Pada saat itu, guru geografi kelas XI IIS B sudah tidak masuk selama 3 pertemuan dikarenakan sakit. Maka guru nya pun digantikan dan peneliti bekerja sama dengan guru pengganti tersebut. Materi yang diajarkan pada tindakan pertama adalah faktor-faktor persebaran flora dan fauna di muka bumi, tindakan kedua membahas persebaran flora dan fauna di Indonesia, tindakan ketiga membahas persebaran flora dan fauna di dunia, dan tindakan keempat membahas tentang keanekaragaman flora dan fauna.

Metode yang digunakan pada penelitian ini adalah Structure Numbered Heads. Metode ini merupakan salah satu metode dari model pembelajaran kooperatif yang mengutamakan kerjasama kelompok. Model pembelajaran kooperatif adalah model pembelajaran yang menuntut peserta didik agar mampu bekerja sama dengan teman-temannya dalam sebuah kelompok untuk memecahkan permasalahan yang diberikan di dalam kelompok tersebut. Banyak tipe atau metode didalam model pembelajaran kooperatif ini salah satunya yaitu Structure Numbered Heads. Metode Structure Numbered Heads merupakan sebuah modifikasi dari metode Numbered Heads Together (Kepala Bernomor). Menurut mengemukakan bahwa dengan "Structure Numbered Heads peserta didik belajar melaksanakan tanggung jawab pribadinya dalam saling keterkaitan dengan rekan- rekan kelompoknya". 5 Perihal motivasi seperti yang diungkapkan oleh Sardiman, bahwa "motivasi dapat juga dikatakan serangkaian usaha untuk menyediakan kondisi-kondisi tertentu, sehingga seseorang mau dan ingin melakukan sesuatu, dan bila ia tidak suka, maka akan berusaha untuk meniadakan atau mengelakkan perasaan tidak suka". ${ }^{6}$ Maka dari itu, menurut peneliti metode ini dirasa cocok untuk dicoba kepada peserta didik untuk meningkatkan motivasi belajar mereka.

Media yang digunakan pada penelitian kali ini berupa slide power point, kertas kerja, nomor dada, Styrofoam, dan kertas karton. Untuk slide power point dan nomor dada digunakan pada setiap pertemuan, kertas kerja digunakan pada pertemuan pertama dan kedua, Styrofoam digunakan pada pertemuan ketiga, dan kertas karton digunakan pada pertemuan ke empat. Media yang berbeda-beda ini digunakan agar para peserta didik tidak merasa bosan dengan penerapan satu metode saja. Maka dari itu, peneliti dan guru mitra berdiskusi agar metode Structure Numbered Heads ini dipadukan dengan teknik lain seperti permainan dan membuat produk dari peserta didik. Contohnya seperti penggunaan Styrofoam pada tindakan ketiga yang digunakan untuk permainan mencocokkan kata dan karton di tindakan keempat yang digunakan para peserta didik untuk membuat produk.

Metode Structure Numbered Heads memiliki beberapa karakteristik seperti yang diungkapkan oleh Miftahul Huda mengemukakan bahwa:

a) Teknik ini merupakan pengembangan dari teknik Kepala Bernomor.

b) Memudahkan pembagian tugas.

c) Memudahkan peserta didik belajar melaksanakan tanggung jawab individunya sebagai anggota kelompok.

d) Dapat diterapkan untuk semua mata pelajaran dan tingkatan kelas. ${ }^{7}$

Pembagian tugas yang peneliti pakai disini disesuaikan dengan keadaan kelas dan materi yang diajarkan. Pada sebagian besar kegiatan belajar kelompok dengan menggunakan Structure Numbered Heads ini masing-masing diberikan diberi tugas untuk mencari bahan ataupun nantinya ditunjuk oleh guru dengan memanggil nomor secara

5 Anita Lie, Kooperatif Learning (Mempraktikekan Kooperati Learning di Ruang-ruang Kelas, (Jakarta: Gramedia, 2007), h.60

6 Sardiman A.M, Interaksi dan Motivasi Belajar Mengajar, (Jakarta Rajawali Pers, 2011), h.75

7 Miftahul Huda,. Cooperative Learning ...h.139 
sembarang, sehingga semua peserta didik selalu siap dan akan melaksanakan tanggung jawabnya dengan sebaik-baiknya. Diinstruksikan juga kepada ketua kelompok agar senantiasa membagi-bagi tugas agar semua anggota nya bekerja dan bertanggung jawab terhadap pekerjaannya. Metode Structure Numbere Heads ini dapat diterapkan pada semua mata pelajaran dan semua tingkatan kelas, karena metode ini mengedepankan kerjasama dan tanggung jawab tiap individu sehingga apapun materi atau permasalahan yang hendak dipecahkan tentu bisa dilalui jika dikerjakan bersama-sama.

\section{Implikasi Model Pembelajaran Kooperatif}

Tipe Structured Numbered Heads Dapat Meningkatkan Motivasi Peserta Didik Pada Mata Pelajaran Geografi Di Kelas XI IIS B SMAN 5 Bandung

Berdasarkan dari hasil penelitian yang sudah dilakukan di kelas XI IIS SMAN 5 Bandung, penerapan pembelajaran dengan metode Structure Numbered Heads sudah mampu meningkatkan motivasi belajar peserta didik pada pembelajaran geografi. Ini bisa dilihat dari peningkatan hasil penelitian pada tindakan I, II, III dan IV. Terutama peningkatan terlihat pada tindakan IV. Penerapan metode pembelajaran Structure Numbered Heads telah menjadikan proses pembelajaran menjadi menarik karena senantiasa menonjolkan peran peserta didik sebagai pembelajar yang aktif di dalam kelas. Structure Numbered Heads menekankan pada peserta didik bahwa tiap individu mempunyai tanggung jawab masing-masing dan pertanggungjawaban hasil kerja kelompok dinilai oleh guru dengan cara memanggil nomor secara sembarang sehingga tiap peserta didik senantiasa harus siap.

Hasil dari tabel perbandingan antara ketiga tindakan yang sudah dilakukan, menunjukkan peningkatan tiap tindakan. Tindakan I dikategorikan rendah, tindakan II dikategorikan cukup, tindakan III dikategorikan baik dan tindakan IV dikategorikan baik. Pada tindakan I, terbilang rendah karena peserta didik yang dipanggil berdasarkan nomor tidak terlihat antusias ketika pembelajaran berlangsung. Itu terlihat dari masih banyak peserta didik yang tidak memperhatikan ketika temannya sedang menjelaskan di depan kelas. Selain itu ada yang masih malu-malu ketika mengungkapkan pendapatnya di depan kelas atau pun ketika menjelaskan di depan terlihat tidak antusias. Dan ada juga yang tidak ikut berdiskusi dengan teman-teman satu kelompoknya.
Berdasarkan hasil dari diskusi dengan guru mitra setelah pembelajaran, pada tindakan II dan III guru mitra sudah bisa mengontrol jalannya pertandingan dan sudah bisa melihat karakterkarakter dari peserta didik yang diajarnya. Hal ini dikarenakan guru mitra yang baru pertama kali mengajar menggantikan guru geografi di kelas XI IIS B ini. Guru asli geografi di kelas XI IIS B ini tidak masuk dari awal ketika dimulainya proses pembelajaran setelah libur semester genap dikarenakan sakit dan dirawat di rumah sakit, maka kurang lebih sudah tiga pertemuan para peserta didik di kelas XI IIS B tidak belajar geografi. Maka saat pertama kali masuk untuk melakukan tindakan I, guru mitra masih meraba-raba kondisi kelas dan peneliti harus melihat kembali bagaimana kondisi para peserta didik ini setelah ditinggal cukup lama tidak belajar geografi.

Melihat hasil dari kegiatan di tindakan IV, sudah mengalami peningkatan yang signifikan. Pada tindakna IV, peserta didik sudah aktif dalam pembelajaran dan antusias mengikuti pembelajaran di kelas. Guru sudah mampu mengaplikasikan dengan optimal apa yangs sudah direncanakan sebelumnya bersama peneliti. Guru sudah mampu menguasai kelas dan mengetahui karakter peserta didik. Guru pun mengantisipasi para peserta didik yang cenderung bisa mengganggu konsentrasi teman-temannya ketika pembelajaran. Peran guru benar-benar sangat vital dan harus seoptimal mungkin dalam menguasai kondisi pembelajaran. Peneliti pun mengambil pembelajaran kooperatif tipe Structure Numbered Heads dalam penelitian ini. Tipe Stucture Numbered Heads dianggap cocok untuk menumbuhkan motivasi belajar peserta didik karena mengedepankan kerjasama kelompok dan tanggung jawab individu. Pengoptimalan penerapan metode di kelas ini dilakukan dengan kolaborasi berbagai teknik dan penampilan produk yang dibuat oleh peserta didik. Kolaborasi ini dilakukan agar para peserta didik tidak merasa bosan.

Terbukti dengan kolaborasi metode Structure Numbered Heads dengan beberapa variasi kegiatan pada tiap tindakan telah mampu meningkatkan motivasi belajar peserta didik. Tindakan I guru mitra dan peneliti menerapkan Structure Numbered Heads secara murni dengan penugasan tiap nomor dan memanggil perwakilan kelompok dengan memanggil nomor secara acak dari tiap kelompok untuk mempresentasikan hasil kerjanya. Tindakan II guru mitra dan peneliti menerapkan Structure 
Numbered Heads dikolaborasi sebagian teknik snowball throwing yaitu tiap kelompok membuat pertanyaan dan dijawab oleh kelompok lain. Tindakan III guru mitra dan peneliti menerapkan Structure Numbered Heads yang dikolaborasi dengan permainan mencocokkan kata pada Styrofoam. Dan tindakan IV guru mitra dan peneliti menerapkan Structure Numbered Heads yang dikolaborasi dengan pembuatan produk pada kertas karton oleh para peserta didik di tiap kelompok.

Dari hasil observasi tiap tindakan dapat dilihat bahwa motivasi belajar peserta didik mengalami peningkatan. Tindakan I dengan kategori "rendah", tindakan II kategori "cukup", tindakan III dengan kategori "baik", dan tindakan IV dengan kategori "baik". Maka melihat hasil observasi tersebut bisa disimpulkan bahwa peneparan pembelajaran model kooperatif tipe Structure Numbered Heads dapat meningkatkan motivasi belajar peserta didik di kelas XI IIS B SMAN 5 Bandung. Ini tidak terlepas dari peran guru yang berhasil menerapkan pembelajaran Structure Numbered Heads di kelas dan juga mampu memberikan stimulus semangat, motivasi dan mengelola kelas pada peserta didik sehingga proses pembelajaran dapat berjalan dengan baik.

Model Structure Numbered Heads merupakan modiikasi dari model Numbered Heads Together sehingga kedua model ini sejenis dalam proses pelaksanaan dan juga penerapannya. Hasil penelitian yang telah dilakukan kali ini sejalan dengan beberapa hasil penelitian seperti yang telah dilakukan sebelumnya seperti penelitian Farah Mawadini dengan judul "Penerapan Metode Pembelajaran Numbered Heads Together Sebagai Upaya Peningkatan Motivasi Belajar Siswa Dalam Pembelajaran Ilmu Pengetahuan Sosial (Ekonomi) Kelas Viiia Sekolah Menengah Pertama Muhammadiyah 7 Surakarta Tahun Ajaran 2011/2012", bahwa numbered heads together sangat efektif dalam peningkatan motivasi belajar. ${ }^{8}$ Maka peneliti mengambil metode modifikasinya yaitu Structure Numbered Heads untuk melakukan peningkatan motivasi belajar peserta didik dan hasilnya pun dapat meningkatkan motivasi belajar.

8 Farah Mawadini, (2012).Penerapan Metode Pembelajaran Numbered Heads Together Sebagai Upaya Peningkatan Motivasi Belajar Siswa Dalam Pembelajaran Ilmu Pengetahuan Sosial (Ekonomi) Kelas Viiia Sekolah Menengah Pertama Mubammadiyah 7 Surakarta Tabun Ajaran 2011/2012. Surakarta: Universitas Muhamadiyah Surakarta
3. Kendala Penerapan Model Pembelajaran Kooperatif Tipe Structure Numbered Heads Untuk Meningkatkan Motivasi Belajar Peserta Didik Pada Mata Pelajaran Geografi

Pada penerapan model pembelajaran kooperatif tipe Structure Numbered Heads terdapat beberapa kendala yang ditemukan oleh guru mitra dan peneliti. Beberapa kendala dan hambatan yang ditemukan pada saat penelitian adalah sebagai berikut:

a) Masih terdapat peserta didik yang kurang aktif. Pada tindakan pertama masih banyak peserta didik yang kurang memahami bagaimana proses pembelajaran dengan metode Structure Numbered Heads. Ketika pembelajaran kelompok pun masih ada peserta didik yang kurang optimal ketika bekerjasama dan lebih mengandalkan temannya satu kelompok untuk menyelesaikan tugas yang diberikan.

b) Motivasi belajar peserta didik masih rendah. Hal ini disebabkan karena masih ada peserta didik yang terlihat kurang antusias ketika pembelajaran berlangsung. Ada beberapa peserta didik yang terlihat bermain-bermain dan tidak membantu temannya mengerjakan tugas di dalam kelompok.

c) Kurang optimalnya metode pembelajaran Structure Numbered Heads. Hal ini disebabkan karena guru yang baru pertama kali masuk setelah tiga pertemuan para peserta didik tidak belajar geografi. Hasilnya, ketika pertama kali belajar dan langsung kepada pembentukan dan pembelajaran kelompok, proses pembelajaran terlihat kurang optimal.

d) Guru yang kurang berpengalaman dalam menyiapkan RPP untuk mencapai keberhasilan dalam Heads, terutama ketika mengkondisikan peserta didik berkumpul dengan kelompoknya dan mempersiapkan kesiapan tiap-tiap kelompok untuk siap belajar.

e) Jam pelajaran di akhir yang membuat para peserta didik merasa pembelajaran dengan metode Structure Numbered Heads.

f) Keterbatasan Waktu. Jam pelajaran yang terkadang kurang pas untuk mengoptimalkan metode Structure Numbered

g) Kebosanan menjadi hambatan yang cukup menyita waktu karena ketika guru mitra dan peneliti masuk ke kelas, ada beberapa peserta didik yang berada di luar kelas karena merasa lelah dan membeli makanan, terkadang pula 
ada yang cukup lama tidak kembali ke kelas.

Melihat dari kendala-kendala di atas, maka cukup banyak hambatan yang diperoleh guru mitra dan peneliti di kelas ketika melakukan penelitian. Beragamnya karakter peserta didik harus menjadi acuan yang perlu diperhatikan lebih lanjut agar apa yang harus dilakukan seorang guru terhadap peserta didik yang kurang memperhatikan pembelajaran bisa ditangani dengan cara yang tepat. Melihat dari segi waktu pun menjadi hal yang perlu diperhatikan, karena ketika jam pelajaran geografi dilaksanakan pada jam terakhir pasti akan memberikan pengaruh psikologis terhadap peserta didik baik itu kejenuhan dari pembelajaran sebelumnya ataupun rasa lelah dan kantuk.

\section{Upaya Untuk Mengatasi Kendala Yang Dihadapi Guru Dalam Penerapan Pembelajaran Dengan Metode Structure Numbered Heads}

Berdasarkan hasil penelitian tindakan yang telah dilakukan serta setelah melihat kendala dan hambatan yang muncul, maka bisa dilihat kendala yang ada lebih kepada guru yang mengajar dan kondisi pembelajaran. Dua hal ini menjadi kendala yang cukup menjadi perhatian dilihat dari paparan yang telah dijelaskan sebelumnya. Guru beserta peneliti haruslah bisa melihat situasi dan kondisi dalam pembelajaran supaya mampu untuk menerapkan teknik yang tepat dalam proses pembelajaran. Setelah melihat kendala yang ada maka peneliti menyusun beberapa upaya untuk mengatasi kendala yang dihadapi guru dalam penerapan pembelajaran dengan metode Structure Numbered Heads, beberapa upaya itu antara lain:

a) Guru dan peneliti harus benar-benar memahami langkah-langkah pembelajaran dengan metode Structure Numbered Heads. Dengan memahami betul langkahlangkahnya secara matang, metode tersebut bisa diterapkan dengan melihat kondisi pembelajaran yang ada dan dikolaborasi sedemikian rupa agar lebih efektif sehingga tidak membosankan bagi peserta didik.

b) Guru senantiasa untuk bisa mengaktifkan peserta didik ketika proses pembelajaran berlangsung. Karena dengan aktifnya peserta didik berarti peserta didik mau untuk untuk belajar dan materi yang diajarkan akan lebih mudah diserap dan dipahami.

c) Guru harus bisa membangkitkan rasa percaya diri peserta didik agar mereka tidak malumalu ketika mengungkapkan pendapatnya di kelas. Guru harus bisa membuat peserta didik nyaman dalam belajar sehingga tidak merasa terintimidasi ataupun tertekan ketika belajar. Jika ada kesulitan yang dihadapi peserta didik hendaknya guru bisa membimbingnya secara halus.

d) Guru harus bisa membangun suasana belajar yang kondusif. Suasana kelas yang kondusif dan menyenangkan harus dibangun dengan membuat pembelajaran yang interaktif antar peserta didik. Dengan pembelajaran yang interaktif antar teman sebayanya, para peserta didik lebih bisa mengeksplor kemampuan nya. Tentu harus dibimbing oleh guru secara baik supaya arah pembicaraan tidak keluar dari materi pembelajaran yang sedang diulas.

e) Guru harus bisa membangkitkan motivasi belajar peserta didik terutama sebelum pembelajaran dimulai. Motivasi sangat penting karena ketika peserta didik tidak memiliki motivasi belajar, maka materi yang disampaikan tidak akan dipahami dengan baik.

f) Guru harus mampu menggali potensi yang dimiliki peserta didik. Sehingga bisa terlihat potensi yang dimiliki dan dari situ guru bisa mengarahkan peserta didik sesuai dengan potensi untuk aktif dalam pembelajaran. Guru harus mampu menggiring peserta didik agar mau belajar dan memberikan sebuah pemahaman pentingnya belajar bagi mereka untuk masa depan.

Hal-hal di atas adalah beberapa upaya yang bisa dilakukan oleh guru untuk mengatasi kendala dalam pembelajaran dengan metode Structure Numbered Heads. Penggunaan metode pembelajaran sesaat sebelum pembelajaran dimulai tentu menjadi tantangan tersendiri yang harus dihadapi seorang guru, karena pastinya banyak hal-hal yang tidak terduga terjadi dari kondisi para peserta didik yang natinya berimbas pada suasana pembelajaran di dalam kelas. Dalam upaya meningkatkan motivasi belajar peserta didik, selayaknya seorang guru memberikan reward pada peserta didik yang lebih unggul di dalam kelas. Bisa diberikan pada yang mau bertanya, memberikan pendapat dan sanggahannya, ataupun yang bisa menjawab pertanyaan dengan tepat. Dengan diberikannya reward maka peserta didik akan lebih termotivasi dan bersemangat ketika 
belajar.

Dari pemaparan yang telah dijelaskan diharapkan mampu mengatasi kendala pembelajaran dengan metode Structure Numbered Heads. Sehingga nantinya pembelajaran dengan metode Structure Numbered Heads pada mata pelajaran geografi ini bisa lebih meningkatkan motivasi belajar peserta didik. Guru bisa menciptakan suasana belajar yang menyenangkan agar para peserta didik lebih nyaman dalam belajar.

Tabel 1. Hasil Observasi Peserta Didik Penelitian Tindakan Kelas

\section{NO Fokus Penelitian}

Respon peserta didik/aktivitas 1 peserta didik dalam pe m belajaran kooperatif tipe structure numbered

$\mathrm{K}$ e $\mathrm{m}$ a $\mathrm{m}$ p u a $\mathrm{n}$ 2 peserta didik dalam memahami isi materi geografi

$\mathrm{K}$ e $\mathrm{m}$ a $\mathrm{m} \mathrm{p}$ u a $\mathrm{n}$ peserta didik dalam mengerjakan tugas nya masing-masing di dalam kelompok

$\mathrm{K}$ e $\mathrm{m} \mathrm{a} \mathrm{m}$ p u a $\mathrm{n}$ peserta didik

4 dalam memberikan pendapatnya dalam diskusi kelompok.

Kemampuan peserta 5 didik untuk bertanya tentang materi geografi

\begin{tabular}{ll}
\hline No & Fokus Penelitian \\
\hline & \\
& K e m a m p u a n \\
& peserta didik dalam \\
menjelaskan materi \\
diskusi di depan \\
teman-temannya \\
sekelasnya
\end{tabular}

Aspek

Ketertarikan peserta didik dalam proses pembelajaran

Keaktifan peserta didik dalam proses pembelajaran

Mampu bertanya tentag hal yang tak dimengerti

Mampu menjawab pertanyaan yang diberikan

Memberikan tambahan ataupun sanggahan

Menulis di lembar kerja

Mencari bahan pengerjaan

Presentasi di depan forum

Bahasanya komunikatif

Antusias dalam menyampaikan

Kesesuaian dengan tema diskusi

Bahasanya mudah dimengerti

Sopan dalam penyampaian

penyampaian

\section{Tindakan $3 \quad$ Tindakan 4}




K e m a m p u a $\mathrm{n}$
peserta didik dalam
menjawab
$\begin{aligned} & \text { pertanyaan } \\ & \text { diberikan yang } \\ & \text { teman-temanny } \\ & \text { ataupun guru }\end{aligned}$

$\mathrm{K}$ e $\mathrm{m}$ a $\mathrm{m} \mathrm{p}$ u a $\mathrm{n}$ peserta didik dalam pertanyaan yang diberikan oleh teman-temannya Ketepatan menjawab sesuai tema diskusi

Bahasanya baik dan jelas

sesui

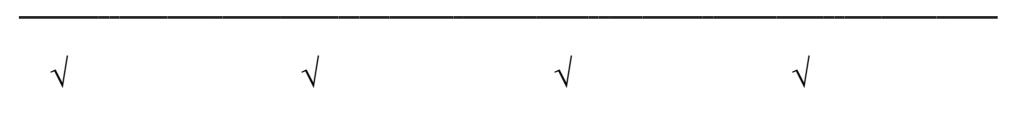

Keterangan:

B : Baik

C : Cukup

$\mathrm{K}$ : Kurang

\section{Penutup}

Berdasarkan penelitian yang telah dilakukan dari tindakan pertama sampai dengan tindakan keempat untuk meningkatkan motivasi belajar peserta didik kesimpulan yang didapatkan adalah bahwa pembelajaran dengan metode Structure Numbered Heads dapat meningkatkan motivasi belajar peserta didik pada mata pelajaran geografi. Hal ini bisa terlihat dari meningkatnya kemampuan peserta didik secara individu seperti ketertarikan peserta didik pada proses pembelajaran, keaktifan peserta didik, mengerjakan tugasnya masing-masing, mengemukakan pendapatnya ketika diskusi, mau bertanya mengenai hal-hal yang tidak dimengerti dan menghargai pendapat temannya.

Pembelajaran dengan metode Structure Numbered Heads dapat meningkatkan motivasi peserta didik terutama pada keaktifan dan kemenarikannya, terlebih guru dan peneliti mengkolaborasikannya dengan beberapa teknik dan permainan pada proses pembelajaran tiap tindakan sehingga tidak membosankan.

\section{E. Daftar Pustaka}

A.M, Sardiman. (2011). Interaksi dan Motivasi Belajar Mengajar. Jakarta Rajawali Pers.

Dimyati dan Mudjiono. (2009). Belajar dan Pembelajaran. Jakarta: Rineka Cipta
Hamalik, Oemar. (2007). Psikologi Belajar dan Mengajar. Bandung: Sinar Baru Algensindo.

Huda, Miftahul. (2013). Cooperative Learning. Yogyakarta: Pustaka Pelajar

Lie, Anita. (2007) Kooperatif Learning (Mempraktikkan Kooperati Learning di Ruang-ruang Kelas, Jakarta: Gramedia.

Madaina Jamil, M. (2012). Tingkat Motivasi Belajar Peserta Didik Berdasarkan Model ARCS Pada Mata Pelajaran Geografi Di SMA/MA Negeri Kota Bandung

Mansyur, A., Rustam, \& Agustina, R. (2008). Peningkatan Aktivitas dan Motivasi Belajar Siswa SMP Negeri 7 Tuban Melalui Pembelajaran Kooperatif TPS

Mawadini, Farah.(2012).Penerapan $M \quad e \quad t \quad o \quad d e$ Pembelajaran Numbered Heads Together Sebagai Upaya Peningkatan Motivasi Belajar Siswa Dalam Pembelajaran Imu Pengetabuan Sosial(Ekonomi) Kelas Viiia Sekolah Menengah Pertama Mubammadiyah 7 Surakarta Tabun Ajaran 2011/2012. Surakarta: Universitas Muhamadiyah Surakarta

Yuni, S. (2013). Peningkatan Motivasi Belajar Siswa Kompetensi Memberikan Layanan Secara Prima Kepada Pelanggan Dengan Metode Pembelajaran Cooperative Script di SMK Karya Rini Yogyakarta 